\title{
COMMENTARY
}

\section{Position Paper: Rapid responses to steroids: current status and future prospects}

\author{
Alexandra Wendler, Elisabetta Baldi ${ }^{1}$, Brian J Harvey ${ }^{2}$, Angel Nadal $^{3}$, Anthony Norman ${ }^{4}$ and Martin Wehling \\ Clinical Pharmacology Mannheim, Faculty of Medicine Mannheim, Ruprecht-Karls-University of Heidelberg, Maybachstrasse 14, D-68169 Mannheim, \\ Germany, ${ }^{1}$ Department of Clinical Physiopathology, University of Florence, Florence, Italy, ${ }^{2}$ Department of Molecular Medicine, Royal College of Surgeons \\ in Ireland, Beaumont Hospital, Dublin 9, Ireland, ${ }^{3}$ Institute of Bioengineering and CIBERDEM, Miguel Hernandez University, Elche, Spain and \\ ${ }^{4}$ Department of Biochemistry and Division of Biomedical Sciences, University of California-Riverside, Riverside, California, USA \\ (Correspondence should be addressed to M Wehling; Email: martin.wehling@medma.uni-heidelberg.de)
}

\begin{abstract}
Steroids exert their actions through several pathways. The classical genomic pathway, which involves binding of steroids to receptors and subsequent modulation of gene expression, is well characterized. Besides this, rapid actions of steroids have been shown to exist. Since 30 years, research on rapid actions of steroids is an emerging field of science. Today, rapid effects of steroids are well established, and are shown to exist for every type of steroid. The classical steroid receptors have been shown to be involved in rapid actions, but there is also strong evidence that unrelated structures mediate these rapid effects. Despite increasing knowledge about the mechanisms and structures which mediate these actions, there is still no unanimous acceptance of this category. This article briefly reviews the history of the field including current controversies and challenges. It is not meant as a broad review of literature, but should increase the awareness of the endocrinology society for rapid responses to steroids. As members of the organizing committee of the VI International Meeting on Rapid Responses to Steroid Hormones 2009, we propose a research agenda focusing on the identification of new receptoral structures and the identification of mechanisms of actions at physiological steroid concentrations. Additionally, efforts for the propagation of translational studies, which should finally lead to clinical benefit in the area of rapid steroid action research, should be intensified.
\end{abstract}

European Journal of Endocrinology 162 825-830

\section{Introduction}

Steroids exert their biological functions through several mechanisms. The classical genomic action of steroids is well established and characterized since decades. Besides this, rapid or nonclassical actions of steroids have been described as early as 1942 when Hans Selye discovered instant anesthetic effects of i.p. injected progesterone in rats (1). These and few other findings especially those originating from Pietras \& Szego (2) in the 1970s remained dormant and in the depository of science until the middle of the 1980s. At that time, related findings were more widely recognized, and the dogma of genomic steroid action as the only available hypothesis was increasingly challenged by the scientific community. Subsequently, from the 1970s up to the time of writing this article, literature on rapid steroid actions developed from about ten papers to a current archive of about 2000 citations.

In the past 10 years, it was shown that classical receptors are involved in rapid signaling involving almost all steroid hormones including thyroid hormone and vitamin D (reviewed in (3)). Membrane-located forms of estrogen and progesterone receptors were identified, and probably exist for other steroid hormone receptors such as glucocorticoid and androgen receptors, as the membrane location may be due to palmitoylation, which also occurs in these receptors $(4,5)$. Several signaling cascades, for example, those involving phosphoinositide-3 kinase, MAPKs, tyrosine kinases, or the JAK/STAT pathways, have been identified (reviewed in (3)).

In the 1990s, the interest in this field increased by findings which did not fit to the involvement of classical receptors. For example, it was demonstrated that rapid effects of aldosterone are not sensitive toward mineralocorticoid receptor inhibitors such as spironolactone. In addition, rapid actions of aldosterone have been shown in cells lacking the classical mineralocorticoid receptor $(6,7)$. These and other data resulted in claims for novel, alternative receptors. Meanwhile, this topic is discussed in a series of international meetings on rapid response to steroid hormones (RRSH) and in specialized section meetings embedded in large congresses, e.g. for endocrinology or neurosciences. 
Table 1 Physiologically relevant rapid actions of steroids.

\begin{tabular}{|c|c|c|c|}
\hline Steroid & Physiologically relevant effect & Involved receptor & References \\
\hline \multirow[t]{3}{*}{ Progesterone } & $\begin{array}{l}\text { Effects on motility and chemotaxis } \\
\text { of human spermatozoa }\end{array}$ & Unknown & Reviewed in Baldi et al. (2009) (16) \\
\hline & $\begin{array}{l}\text { Increase of intracellular calcium } \\
\text { in human sperm }\end{array}$ & Unknown & Baldi et al. (1991) (24) \\
\hline & Acrosome reaction in human sperm & Unknown & $\begin{array}{l}\text { Morales et al. (1992) (25) reviewed } \\
\text { in Baldi et al. (2009) (16) }\end{array}$ \\
\hline \multirow[t]{6}{*}{ Aldosterone } & $\begin{array}{l}\text { Regulation of cell volume in } \\
\text { human mononuclear leukocytes }\end{array}$ & Unknown & Wehling et al. (1991) (26) \\
\hline & $\begin{array}{l}\text { Vasoconstriction of resistance } \\
\text { arteries in male humans }\end{array}$ & Unknown & Romagni et al. (2003) (27) \\
\hline & Alternation in $\mathrm{pH}$ in MDCK cells & Unknown & Gekle et al. (1996) (28) \\
\hline & $\begin{array}{l}\text { Inflammation, hypertrophy, fibrosis } \\
\text { in rat heart }\end{array}$ & $\begin{array}{l}\text { Classical mineralocorticoid } \\
\text { receptor }\end{array}$ & $\begin{array}{l}\text { Rocha et al. (2002) (29), } \\
\text { Young et al. (1994) (30) } \\
\text { and Sun et al. (2002) (31) }\end{array}$ \\
\hline & $\mathrm{ENaC}$ trafficking in renal $\mathrm{CCD}$ cells & $\begin{array}{l}\text { Classical mineralocorticoid } \\
\text { receptor }\end{array}$ & McEneaney et al. (2008) (32) \\
\hline & PKD signaling in renal cell proliferation & $\begin{array}{l}\text { Classical mineralocorticoid } \\
\text { receptor }\end{array}$ & McEneaney et al. (2009) (33) \\
\hline \multirow[t]{7}{*}{ Estrogen } & $\begin{array}{l}\text { Rapid vasodilation in postmenopausal } \\
\text { women }\end{array}$ & Classical estrogen receptor? & Gilligan et al. (1994) (34) \\
\hline & $\begin{array}{l}\text { Activation of ERK in uterine arterial } \\
\text { endothelial cells from pregnant ewes }\end{array}$ & Classical estrogen receptor & Chen et al. (2004) (35) \\
\hline & $\begin{array}{l}\text { Activation of nitric oxide synthase in } \\
\text { endothelial cells of rat adipocytes }\end{array}$ & Classical estrogen receptor & Jaubert et al. (2007) (36) \\
\hline & $\begin{array}{l}\text { Increase in [Ca] in chicken and pig } \\
\text { granulosa cells, triggered by inositol } \\
\text { 1,4,5-trisphosphate }\end{array}$ & Unknown & $\begin{array}{l}\text { Morley et al. (1998) (37), Shears } \\
\text { (1991) (38) and Eppig (1991) (39) }\end{array}$ \\
\hline & $\begin{array}{l}\text { Activation of ERK and increase in } \\
\text { insulin biosynthesis }\end{array}$ & Estrogen receptor $\alpha$ & Alonso-Magdalena et al. (2008) (40) \\
\hline & Insulinotropic action & Estrogen receptor $\beta$ & $\begin{array}{l}\text { Nadal et al. (1998) (41) and Soriano } \\
\text { et al. (2009) (42) }\end{array}$ \\
\hline & $\begin{array}{l}\text { Female sex-specific antisecretory } \\
\text { responses in intestine }\end{array}$ & $\begin{array}{l}\text { Membrane estrogen } \\
\text { receptor } \alpha\end{array}$ & O'Mahony et al. $(2009)(43,44)$ \\
\hline \multirow[t]{5}{*}{ Vitamin D } & $\begin{array}{l}\text { Effects on membrane-gated calcium } \\
\text { channels, phospholipase C activity, } \\
\text { and the sodium/hydrogen antiport in } \\
\text { osteoblasts }\end{array}$ & Vitamin D receptor & $\begin{array}{l}\text { Norman et al. (2002) (45) and } \\
\text { Huhtakangas et al. (2004) (46) }\end{array}$ \\
\hline & $\begin{array}{l}\text { Opening of chloride channels in } \\
\text { osteoblasts requires intact VDR }\end{array}$ & Vitamin D receptor & Zanello et al. (2004) (47) \\
\hline & $\begin{array}{l}\text { In keratinocytes and in vivo in skin: } \\
\text { protection against u.v.-induced DNA } \\
\text { damage }\end{array}$ & Vitamin D receptor & Dixon et al. (2007) (48) \\
\hline & $\begin{array}{l}\text { VDR is present in T-tubule membranes } \\
\text { of heart muscle cells, and is associated } \\
\text { with myocyte contraction }\end{array}$ & Vitamin D receptor & Tishkoff et al. (2008) (49) \\
\hline & $\begin{array}{l}\text { Alternations of cytosolic calcium } \\
\text { concentration in mouse osteoblasts }\end{array}$ & Unknown & Lieberherr (1987) (50) \\
\hline \multirow[t]{2}{*}{ Thyroid hormones } & $\begin{array}{l}\text { Formation of new blood vessels } \\
\text { in the chick chorioallantoic } \\
\text { membrane model }\end{array}$ & Integrin $\alpha_{v} \beta_{3}$ & Davis et al. (2004) (51) \\
\hline & ERK/MAPK activation in CV-1 cells & $\begin{array}{l}\text { Classical thyroid hormone } \\
\text { receptor }\end{array}$ & Davis et al. (2000) (52) \\
\hline \multirow[t]{5}{*}{ Androgens } & $\begin{array}{l}\text { Alternation of calcium levels in } \\
\text { activated T-cells, male rat osteoblasts }\end{array}$ & Unknown & $\begin{array}{l}\text { Benten et al. (1997) (53) and } \\
\quad \text { Lieberherr \& Grosse (1994) (54) }\end{array}$ \\
\hline & $\begin{array}{l}\text { Activation of MAPK kinases in prostate } \\
\text { cancer cells }\end{array}$ & $\begin{array}{l}\text { Classical androgen } \\
\text { receptor }\end{array}$ & Peterziel et al. (1999) (55) \\
\hline & $\begin{array}{l}\text { Prolactin release from lactotrophs } \\
\text { (type 2) in the male pituitary }\end{array}$ & Unknown & Christian et al. (2000) (56) \\
\hline & $\begin{array}{l}\text { Antiproliferative effect of testosterone } \\
\text { on LNCaP human prostate cancer cells }\end{array}$ & $\begin{array}{l}\text { Membrane androgen } \\
\text { receptor }\end{array}$ & Hatzoglou et al. (2005) (57) \\
\hline & $\begin{array}{l}\text { Proliferative effect of dihydrotestosterone } \\
\text { on human breast cancer cells }\end{array}$ & Integrin $\alpha_{v} \beta_{3}$ & Lin et al. (2009) (58) \\
\hline
\end{tabular}

Physiological concentrations of the different steroids used as eligibility criterion: progesterone: $\mathrm{pM}-\mu \mathrm{M}$ (dependent on the site of action); estradiol: up to $10 \mathrm{nM}$ aldosterone $0.1 \mathrm{nM} ; 1 \alpha, 25(\mathrm{OH}) 2$-vitamin $\mathrm{D}_{3}$ : $1-0.1 \mathrm{nM}$ in plasma; thyroid hormones: $0.01 \mathrm{nM}$; androgen: $0.1-10 \mathrm{nM}$ (dependent on the site of action); glucocorticoids: $10 \mathrm{nM}$ (free cortisol). 


\section{Nonclassical receptors for rapid steroid action}

Besides the rapid actions of steroids mediated through classical receptors, there are several examples of alternative molecules which mediate these rapid actions. Often, these are already known proteins, with distinct biological functions. For example, there is strong evidence that integrins mediate rapid effects of thyroid hormones (8). The digitalis receptor (digitalis being a steroid) is a membrane enzyme, namely sodiumpotassium ATPase (9). The odorant receptors, through which we may smell steroidal pheromones, have not been identified yet, but they must exist (10). In plants, brassinosteroids do not stimulate transcription, but bind to transmembrane receptor kinases (11). Additionally, it was demonstrated that neurosteroids act through GABA receptors (12). Current data suggest that neurosteroids may alternatively act via an as yet unidentified G-protein-coupled receptor (13). The identification of completely unknown structures, which may mediate rapid steroid actions, has turned out to be difficult. All evidences for alternative membrane receptors transmitting rapid steroid action, which are not related to known structures, are still controversially discussed. This particularly applies to GPR30 as a potential receptor for estrogen and the membrane progesterone receptor $(14,15)$.

\section{Physiological and pharmacological relevance of rapid steroid actions}

A conceptual problem of many studies dealing with rapid steroid actions is the use of very high, supraphysiological steroid concentrations. This renders the identification of physiologically relevant rapid actions of steroids difficult. Table 1 summarizes some examples of steroid effects observed at physiological concentrations. It is important to consider the concentration of the steroid at the site of action, which may significantly differ from the circulating one. Progesterone may serve as an example: in the case of sperm stimulation, it is present at very high concentrations (exceeding plasma levels by a factor of 1000) at the site of action (reviewed in (16)). In general, experiments using physiological concentrations of steroids at their site of action must be encouraged in future studies to better identify the physiological role of rapid steroid effects.

Nevertheless, also rapid actions of steroids mediated by supraphysiological concentrations may be relevant in pharmacological use, and therefore have clinical implications. Examples for this are the use of glucocorticoids to decrease the airway mucosal blood flow in asthma patients (17), the use of these steroids in acute phases of rheumatic diseases (18), and the use of neuroactive steroids as anesthetics or antidepressants (19).

Another problem that has received little attention until now is the fact that circulating hormone levels do not change rapidly, and therefore rapid effects should be persistent. Comparably little is known about the desensitization processes and secondary genomic impact of nongenomically initiated steroid actions which have been shown to exist (20).

\section{Translational relevance}

In the 1990s, there was great enthusiasm and hope to utilize the novel findings on rapid steroid hormone action for improved patient care. Overall, this hope has not been realized. In the past 15-20 years, no drug based on any kind of mechanism of rapid steroid action has been developed and marketed. However, some steroids that act rapidly, for example, glucocorticoids which are used in acute rheumatic diseases, have been used therapeutically for many years (18). In Table 2, the few successfully translated rapid actions of steroids are summarized. Most of them have been translated years ago without recognition of the rapid effect they are based on.

Furthermore, there are promising candidates which either are being developed or await funding to be taken into development. A prominent example is STX (2-(4-hydroxyphenyl)-3-phenylpent-2-enoic acid (4-(2-dimethylaminorthoxy)-phenyl)amide, E isomer), a selective estrogen receptor modulator (SERM), with potential impact on menopause symptoms and antiobesity effects, which has been shown to act rapidly (21). The deaminated thyroid hormone analog tetrac may be useful in the treatment of cancer (22).

Table 2 Rapid steroid actions that have already been successfully translated (in part unwittingly).

\begin{tabular}{lc}
\hline Steroid action & Clinical use \\
\hline Anesthetic effects of progestins & $\begin{array}{c}\text { Althesin (mixture of alphaxolone and alphadolone) was formerly } \\
\text { used in humans, but was stopped due to severe side effects, and } \\
\text { is still in use in veterinary medicine (59) }\end{array}$ \\
$\begin{array}{c}\text { Fluticasone and budesonide decrease the airway } \\
\text { mucosal blood flow }\end{array}$ & $\begin{array}{l}\text { Acute phases or particular severe forms of rheumatic diseases such } \\
\text { as lupus erythematosus, vasculitis, polymyositis, and rheumatoid } \\
\text { arthritis (17) }\end{array}$ \\
\hline
\end{tabular}


For vitamin D analogs, a role as anticancer and diabetes-preventing agents has been proposed based on their extranuclear effects (23).

\section{Recommendations}

The organizing committee of the RRSH series states that

i) There is evidence for rapid steroid effects through both classic steroid receptors and unrelated structures presumably residing in biological membranes.

Future research should be focused on rapid physiological effects of steroid hormones to elucidate the involved biological pathways. Therefore, it is important that the concentrations used in the experiments are critically reflected. Studies analyzing rapid effects of steroids in cell lines and isolated tissues should be translated into intact animal models. Furthermore, the careful analysis of dose dependence of these effects in physiological concentrations is necessary. The pharmacodynamics of the involved receptors is another important issue, which should be analyzed in the future.

ii) The identification of new 'receptoral structures' that mediate rapid actions is difficult and, until now, most approaches have failed to do this or led to contradictory results. Future research should focus on the identification and validation of these structures. The difficulties of these approaches should also be recognized and appreciated by the funding agencies.

iii) Increased emphasis must be placed on possible clinical application of experimentally demonstrated rapid actions of steroids. Until now, only limited translational success in the area of rapid responses to steroid hormones is evident. However, there are promising candidates, and others should urgently be identified and developed into potential drugs. Basic researchers are encouraged to seek advice from clinically oriented or translationally experienced researchers.

As a general concern, we anticipate that the area could face increasing funding problems if research were consumed by the very prominent area of classic steroid receptor research, or no clinical applications became evident in the near future.

Thus, this position paper stresses that the scientific community, funding agencies, and journal editors should structurally and financially acknowledge the opportunities of rapid and nonclassical steroid research. Scientists from neighboring areas (for example, those working on G-proteins or other rapid signaling pathways, or researchers from clinical areas of relevance, such as rheumatic diseases) should be involved in the opportunities and challenges of this still novel research field.

\section{Declaration of interest}

The authors declare that there is no conflict of interest that could be perceived as prejudicing the impartiality of the research reported. M Wehling received consulting and lecture fees from Pfizer, Novartis, Lilly, NovoNordisk and Daiichi-Sankyo.

\section{Funding}

B J Harvey received research grants for this research.

\section{References}

1 Seyle H. Correlations between the chemical structure and the pharmacological actions of the steroids. Endocrinology 194230 437-453.

2 Pietras RJ \& Szego CM. Steroid hormone-responsive, isolated endometrial cells. Endocrinology 197596 946-954.

3 Losel RM, Falkenstein E, Feuring M, Schultz A, Tillmann HC, Rossol-Haseroth K \& Wehling M. Nongenomic steroid action: controversies, questions, and answers. Physiological Reviews 2003 83 965-1016.

4 Hammes SR \& Levin ER. Extranuclear steroid receptors: nature and actions. Endocrine Reviews 200728 726-741.

5 Marino $M$ \& Ascenzi P. Steroid hormone rapid signaling: the pivotal role of S-palmitoylation. IUBMB Life $2006 \mathbf{5 8} 716-719$.

6 Wehling M, Eisen C \& Christ M. Aldosterone-specific membrane receptors and rapid non-genomic actions of mineralocorticoids. Molecular and Cellular Endocrinology 199290 C5-C9.

7 Haseroth K, Gerdes D, Berger S, Feuring M, Gunther A, Herbst C, Christ M \& Wehling M. Rapid nongenomic effects of aldosterone in mineralocorticoid-receptor-knockout mice. Biochemical and Biophysical Research Communications 1999266 257-261.

8 Bergh JJ, Lin HY, Lansing L, Mohamed SN, Davis FB, Mousa S \& Davis PJ. Integrin $\alpha_{v} \beta_{3}$ contains a cell surface receptor site for thyroid hormone that is linked to activation of mitogen-activated protein kinase and induction of angiogenesis. Endocrinology 2005 146 2864-2871.

9 Akera T. Membrane adenosine triphosphatase: a digitalis receptor? Science 1977198 569-574.

10 Pick H, Etter S, Baud O, Schmauder R, Bordoli L, Schwede T \& Vogel H. Dual activities of odorants on olfactory and nuclear hormone receptors. Journal of Biological Chemistry 2009284 30547-30555.

11 Belkhadir Y, Wang X \& Chory J. Brassinosteroid signaling pathway. Science Signalling $20062006 \mathrm{~cm} 4$.

12 Lampert J. Neurosteroids: endogenous allosteric modulators of GABA(A) receptors. Psychoneuroendocrinology 200934 548-558.

13 Charalampopoulos I, Alexaki VI, Lazaridis I, Dermitzaki E, Avlonitis N, Tsatsanis C, Calogeropoulou T, Margioris AN, Castanas E \& Gravanis A. G protein-associated, specific membrane binding sites mediate the neuroprotective effect of dehydroepiandrosterone. FASEB Journal 200620 577-579.

14 Otto C, Fuchs I, Kauselmann G, Kern H, Zevnik B, Andreasen P, Schwarz G, Altmann H, Klewer M, Schoor M, Vonk R \& Fritzemeier KH. GPR30 does not mediate estrogenic responses in reproductive organs in mice. Biology of Reproduction 200980 34-41.

15 Krietsch T, Fernandes MS, Kero J, Losel R, Heyens M, Lam EW, Huhtaniemi I, Brosens JJ \& Gellersen B. Human homologs of the putative $G$ protein-coupled membrane progestin receptors $(\mathrm{mPR} \alpha, \beta$, and $\gamma)$ localize to the endoplasmic reticulum and are not activated by progesterone. Molecular Endocrinology 200620 3146-3164. 
16 Baldi E, Luconi M, Muratori M, Marchiani S, Tamburrino L \& Forti G. Nongenomic activation of spermatozoa by steroid hormones: facts and fictions. Molecular and Cellular Endocrinology 2009308 39-46.

17 Buttgereit F. Mechanisms and clinical relevance of nongenomic glucocorticoid actions. Zeitschrift für Rheumatologie $2000 \mathbf{5 9}$ II/119-II/123.

18 Wanner A, Horvath G, Brieva JL, Kumar SD \& Mendes ES. Nongenomic actions of glucocorticosteroids on the airway vasculature in asthma. Proceedings of the American Thoracic Society 2004 1 235-238.

19 Belelli D, Herd MB, Mitchell EA, Peden DR, Vardy AW, Gentet L \& Lambert JJ. Neuroactive steroids and inhibitory neurotransmission: mechanisms of action and physiological relevance. Neuroscience 2006138 821-829.

20 Vasudevan N \& Pfaff DW. Non-genomic actions of estrogens and their interaction with genomic actions in the brain. Frontiers in Neuroendocrinology $200829238-257$.

21 Qiu J, Bosch MA, Tobias SC, Grandy DK, Scanlan TS, Ronnekleiv OK \& Kelly MJ. Rapid signaling of estrogen in hypothalamic neurons involves a novel G-protein-coupled estrogen receptor that activates protein kinase C. Journal of Neuroscience 200323 9529-9540.

22 Davis PJ, Zhou M, Davis FB, Lansing L, Mousa SA \& Lin HY. Mini-review: cell surface receptor for thyroid hormone and nongenomic regulation of ion fluxes in excitable cells. Physiology and Behavior 200999 237-239.

23 Reichrath J. Will analogs of 1,25-dihydroxyvitamin D(3) (calcitriol) open a new era in cancer therapy? Onkologie 2001 24 128-133.

24 Baldi E, Casano R, Falsetti C, Krausz C, Maggi M \& Forti G. Intracellular calcium accumulation and responsiveness to progesterone in capacitating human spermatozoa. Journal of Andrology 199112 323-330.

25 Morales P, Llanos M, Gutierrez G, Kohen P, Vigil P \& Vantman D. The acrosome reaction-inducing activity of individual human follicular fluid samples is highly variable and is related to the steroid content. Human Reproduction 19927 646-651.

26 Wehling M, Kasmayr J \& Theisen K. Rapid effects of mineralocorticoids on sodium-proton exchanger: genomic or nongenomic pathway? American Journal of Physiology 1991260 E719-E726.

27 Romagni P, Rossi F, Guerrini L, Quirini C \& Santiemma V. Aldosterone induces contraction of the resistance arteries in man. Atherosclerosis $2003 \mathbf{1 6 6} 345-349$.

28 Gekle M, Golenhofen N, Oberleithner H \& Silbernagl S. Rapid activation of $\mathrm{Na}^{+} / \mathrm{H}^{+}$exchange by aldosterone in renal epithelial cells requires $\mathrm{Ca}^{2+}$ and stimulation of a plasma membrane proton conductance. PNAS 199693 10500-10504.

29 Rocha R, Rudolph AE, Frierdich GE, Nachowiak DA, Kekec BK, Blomme EA, McMahon EG \& Delyani JA. Aldosterone induces a vascular inflammatory phenotype in the rat heart. American Journal of Physiology. Heart and Circulatory Physiology 2002283 H1802-H1810.

30 Young M, Fullerton M, Dilley R \& Funder J. Mineralocorticoids, hypertension, and cardiac fibrosis. Journal of Clinical Investigation $1994932578-2583$.

31 Sun Y, Zhang J, Lu L, Chen SS, Quinn MT \& Weber KT. Aldosterone-induced inflammation in the rat heart: role of oxidative stress. American Journal of Pathology 2002161 1773-1781.

32 McEneaney V, Harvey BJ \& Thomas W. Aldosterone regulates rapid trafficking of epithelial sodium channel subunits in renal cortical collecting duct cells via protein kinase D activation. Molecular Endocrinology 200822 881-892.

33 McEneaney V, Dooley R, Harvey BJ \& Thomas W. Protein kinase D stabilizes aldosterone-induced ERK1/2 MAP kinase activation in M1 renal cortical collecting duct cells to promote cell proliferation. Journal of Steroid Biochemistry and Molecular Biology 2009118 $18-28$.
34 Gilligan DM, Quyyumi AA \& Cannon RO III. Effects of physiological levels of estrogen on coronary vasomotor function in postmenopausal women. Circulation $1994892545-2551$.

35 Chen DB, Bird IM, Zheng J \& Magness RR. Membrane estrogen receptor-dependent extracellular signal-regulated kinase pathway mediates acute activation of endothelial nitric oxide synthase by estrogen in uterine artery endothelial cells. Endocrinology 2004 $145113-125$.

36 Jaubert AM, Mehebik-Mojaat N, Lacasa D, Sabourault D, Giudicelli Y \& Ribiere C. Nongenomic estrogen effects on nitric oxide synthase activity in rat adipocytes. Endocrinology $2007 \mathbf{1 4 8}$ 2444-2452.

37 Morley P, Whitfield JF, Vanderhyden BC, Tsang BK \& Schwartz JL. A new, nongenomic estrogen action: the rapid release of intracellular calcium. Endocrinology 1992131 1305-1312.

38 Shears SB. Regulation of the metabolism of 1,2-diacylglycerols and inositol phosphates that respond to receptor activation. Pharmacology and Therapeutics 1991 49 79-104.

39 Eppig JJ. Intercommunication between mammalian oocytes and companion somatic cells. BioEssays 199113 569-574.

40 Alonso-Magdalena P, Ropero AB, Carrera MP, Cederroth CR, Baquie M, Gauthier BR, Nef S, Stefani E \& Nadal A. Pancreatic insulin content regulation by the estrogen receptor ER $\alpha$. PLoS ONE 20083 e2069.

41 Nadal A, Rovira JM, Laribi O, Leon-quinto T, Andreu E, Ripoll C \& Soria B. Rapid insulinotropic effect of $17 \beta$-estradiol via a plasma membrane receptor. FASEB Journal 199812 1341-1348.

42 Soriano S, Ropero AB, Alonso-Magdalena P, Ripoll C, Quesada I, Gassner B, Kuhn M, Gustafsson JA \& Nadal A. Rapid regulation of $\mathrm{K}(\mathrm{ATP})$ channel activity by $17 \beta$-estradiol in pancreatic $\beta$-cells involves the estrogen receptor $\beta$ and the atrial natriuretic peptide receptor. Molecular Endocrinology 200923 1973-1982.

43 O'Mahony F, Alzamora R, Chung HL, Thomas W \& Harvey BJ. Genomic priming of the antisecretory response to estrogen in rat distal colon throughout the estrous cycle. Molecular Endocrinology 200923 1885-1899.

44 O'Mahony F, Thomas W \& Harvey BJ. Novel female sex-dependent actions of oestrogen in the intestine. Journal of Physiology 2009 $\mathbf{5 8 7}$ 5039-5044.

45 Norman AW, Olivera CJ, Barreto Silva FR \& Bishop JE. A specific binding protein/receptor for 1 1 ,25-dihydroxyvitamin $\mathrm{D}(3)$ is present in an intestinal caveolae membrane fraction. Biochemical and Biophysical Research Communications 2002298 414-419.

46 Huhtakangas JA, Olivera CJ, Bishop JE, Zanello LP \& Norman AW. The vitamin $\mathrm{D}$ receptor is present in caveolae-enriched plasma membranes and binds $1 \alpha, 25(\mathrm{OH}) 2$-vitamin $\mathrm{D}_{3}$ in vivo and in vitro. Molecular Endocrinology 200418 2660-2671.

47 Zanello LP \& Norman AW. Rapid modulation of osteoblast ion channel responses by $1 \alpha, 25(\mathrm{OH}) 2$-vitamin $\mathrm{D}_{3}$ requires the presence of a functional vitamin D nuclear receptor. PNAS 2004 101 1589-1594.

48 Dixon KM, Deo SS, Norman AW, Bishop JE, Halliday GM, Reeve VE \& Mason RS. In vivo relevance for photoprotection by the vitamin $\mathrm{D}$ rapid response pathway. Journal of Steroid Biochemistry and Molecular Biology $2007 \mathbf{1 0 3} 451-456$.

49 Tishkoff DX, Nibbelink KA, Holmberg KH, Dandu L \& Simpson RU. Functional vitamin D receptor (VDR) in the t-tubules of cardiac myocytes: VDR knockout cardiomyocyte contractility. Endocrinology 2008149 558-564.

50 Lieberherr M. Effects of vitamin $D_{3}$ metabolites on cytosolic free calcium in confluent mouse osteoblasts. Journal of Biological Chemistry 1987262 13168-13173.

51 Davis FB, Mousa SA, O'Connor L, Mohamed S, Lin HY, Cao HJ \& Davis PJ. Proangiogenic action of thyroid hormone is fibroblast growth factor-dependent and is initiated at the cell surface. Circulation Research 200494 1500-1506.

52 Davis PJ, Shih A, Lin HY, Martino LJ \& Davis FB. Thyroxine promotes association of mitogen-activated protein kinase and nuclear thyroid hormone receptor (TR) and causes serine phosphorylation of TR. Journal of Biological Chemistry 2000275 38032-38039. 
53 Benten WP, Lieberherr M, Sekeris CE \& Wunderlich F. Testosterone induces $\mathrm{Ca}^{2+}$ influx via non-genomic surface receptors in activated T cells. FEBS Letters 1997407 211-214.

54 Lieberherr M \& Grosse B. Androgens increase intracellular calcium concentration and inositol 1,4,5-trisphosphate and diacylglycerol formation via a pertussis toxin-sensitive G-protein. Journal of Biological Chemistry 1994269 7217-7223.

55 Peterziel H, Mink S, Schonert A, Becker M, Klocker H \& Cato AC. Rapid signalling by androgen receptor in prostate cancer cells. Oncogene 199918 6322-6329.

56 Christian HC, Rolls NJ \& Morris JF. Nongenomic actions of testosterone on a subset of lactotrophs in the male rat pituitary. Endocrinology 2000141 3111-3119.

57 Hatzoglou A, Kampa M, Kogia C, Charalampopoulos I, Theodoropoulos PA, Anezinis P, Dambaki C, Papakonstanti EA, Stathopoulos EN, Stournaras C, Gravanis A \& Castanas E
Membrane androgen receptor activation induces apoptotic regression of human prostate cancer cells in vitro and in vivo. Journal of Clinical Endocrinology and Metabolism 200590 893-903.

58 Lin HY, Sun M, Lin C, Tang HY, London D, Shih A, Davis FB \& Davis PJ. Androgen-induced human breast cancer cell proliferation is mediated by discrete mechanisms in estrogen receptor- $\alpha$-positive and -negative breast cancer cells. Journal of Steroid Biochemistry and Molecular Biology 2009113 182-188.

59 Clarke RS, Dundee JW \& Carson IW. Proceedings: a new steroid anaesthetic - althesin. Proceedings of the Royal Society of Medicine 197366 1027-1030.

Received 15 February 2010

Accepted 26 February 2010 